\title{
PELATIHAN PRAKTIK PENGELASAN BAGI MANTAN TENAGA KERJA INDONESIA (TKI) DI JAKARTA
}

\author{
Agus Dudung-Fakultas Teknik Universitas Negeri Jakarta, \\ Sugeng Priyanto - Fakultas Teknik Universitas Negeri Jakarta, \\ Diah Armeliza - Fakultas Ekonomi Universitas Negeri Jakarta
}

\begin{abstract}
ABSTRAK
Bagi para mantan tenaga kerja indonesia yang tidak kembali lagi ke luar negeri, tidaksedikit pengangguran atau tanpa pekerjaan, mengingat bekal pengetahuan dan keterampilan yang minim, rasanya sulit untuk bekerja di sektor formal sebagai pegawai kantor atau perusahaan, apalagi daya tampung sektor ini terbatas.

Dengan melihat kondisi para TKI, pengangguran tidak memiliki bekal keterampilan yang dapat diandalkan sebagai pekerja. Maka salah satu bentuk keterampilan Las. Adapun Tujuan kegiatan ini adalah sebagai berikut: (1)Meningkatkan kompetensi sumber daya manusia, khususnya para mantan TKI, untuk mencapai standar kompetensi yang ditetapkan dalam peraturan perundangan yang berlaku. (2) Memutakhirkan kompetensi keterampilan para mantan TKI untuk memenuhi kebutuhan tenaga kerja, dalam perkembangan ilmu pengetahuan, dan teknologi untuk memfasilitasi proses sumber daya manusia yang berkualitas. (3) Meningkatkan sumber daya manusia dalam melaksanakan tugas pokok dan fungsinya sebagai tenaga profesional. (4) Menunjang pengembangan karir para mantan TKI di bidang pengelasan. Khalayak Sasaran Para Mantan Tenaga kerja Indonesia ( TKI) yang tidak pergi lagi ke luar negeri dan belum dapat pekerjaan tetap, dan mereka bekerja serabutan di jakarta. Para mantan TKI ini berasal dari Desa Teluk Labuan Pandeglang. Berdasarkan pengamatan yang dilakukan, pelaksanaan kegiatan pengabdian ini berhasil dengan baik. Penguasaan teknik pengelasan juga cukup baik lebih dari 85\% peserta menguasai teknik yang baik dan benar, walaupun belum dapat dikatakan mahir.
\end{abstract}

Kata Kunci: Pengelasan, TKI

\section{A. ANALISIS SITUASI}

Tenaga Kerja Indonesia (disingkat TKI) adalah sebutan bagi warga negara Indonesia yang lowlife dan unskill yang bekerja di luar negeri (seperti Malaysia, Timur Tengah, Taiwan, uganda dan somalia) dalam hubungan kerja untuk jangka waktu tertentu dengan menerima upah. Namun, istilah TKI seringkali dikonotasikan dengan pekerja kasar karena TKI sejatinya memang adalah kumpulan tenaga kerja unskill yang merupakan program pemerintah untuk menekan angka pengangguran. TKI perempuan seringkali disebut Tenaga Kerja Wanita (TKW). TKI sering disebut sebagai pahlawan devisa karena dalam setahun bisa menghasilkan devisa triliun rupiah, tetapi dalam kenyataannya, TKI menjadi ajang pungli bagi para pejabat dan agen terkait. Pada 9 Maret 2007 kegiatan operasional di bidang Penempatan dan Perlindungan TKI di luar negeri dialihkan menjadi tanggung jawab BNP2TKI. Sebelumnya seluruh kegiatan operasional di bidang Penempatan dan Perlindungan Tenaga Kerja Indonesia di luar negeri dilaksanakan oleh Ditjen Pembinaan dan Penempatan Tenaga Kerja Luar Negeri (PPTKLN) Depnakertrans.

Bagi para mantan tenaga kerja indonesia yang tidak kembali lagi ke luar negeri, tidak sedikit pengangguran atau tanpa pekerjaan, mengingat bekal pengetahuan dan keterampilan yang minim, rasanya sulit untuk bekerja di sektor formal sebagai pegawai kantor atau perusahaan, apalagi daya tampung sektor ini terbatas.

Di situasi pada saat ini dimana ekonomi tidak menentu, dan telah terjadi ledakkan jumlah penggangguran dikalangan pemuda dan remaja dan ditambah dengan pemutusan hubungan kerja (PHK) di asal mereka bekerja karena perusahaan gulung tikar (bangkrut). Dampak yang ditimbulkan dari kondisi ini, akan bertambahnya jumlah pengangguran. Karena jumlah pengangguran dan pemuda TKI semakin para sebagai dampak krisis ekonomi dan dampak sosial dari ini nyata 
telah terjadi. Oleh karena itu diperlukan uluran tangan dari pihak lain, misalnya Perguruan Tinggi lewat program pengambdian kepada masyarakat untuk dapat memecahkan masalah ini. Kondisi di atas perlu segera mendapat penanganan melalui pemberdayaan masyarakat terutama para pemuda dengan memanfaatkan potensi dan sumberdaya yang ada. Salah satu bentuk pemberdayaan mereka adalah dengan membekali keterampilan yang dapat dimanfaatkan langsung, yaitu dapat dijadikan sebagai pekerja yang mendatangkan penghasilan. Dengan melihat kondisi para TKI, pengangguran tidak memiliki bekal keterampilan yang dapat diandalkan sebagai pekerja. Maka salah satu bentuk keterampilan Las.

\section{MATERI}

1. Pengenalan dan cara penggunaan alat-alat pendukung mesin las

2. Praktik pengelasan

3. Pengukuran dalam pengelasan

4 Membuat dan mengerjakan propil pagar dan propil pintu

\section{Perumusan Masalah}

Bagaimana meningkatkan keterampilan mengelas pagi para mantan Tenaga Kerja Indonesia (TKI)?

\section{Manfaat Kegiatan}

Kegiatan pengabdian kepada masyarakat ini mempunyai beberapa manfaat sebagai berikut:

1. Bagi sasaran para peserta pelatihan (khusus mantan TKI) dapat meningkatkan kualitas sumberdaya manusia, dari semula tidak terampil menjadi lebih terampil dan mempunyai keahlian menjadikan terampil bidang pengelasan yang professional.

2. Menjadikan para peserta pelatihan (khusus mantan TKI) yang berkualitas sesuai dengan bidangnya di pengelasan.

3. Membantu masyarakat mantan TKI dalam meningkatkan kualitas kehidupan.

4. Sebagai upaya membantu pemerintah dalam mengatasi pengangguran, sehingga diharapkan para peserta dapat membuka usaha bengkel las.

5. Meningkatan kualitas masyarakat Indonesia dalam bidang keterampilan pengelasan.

\section{TINJAUAN PUSTAKA \\ Pengelasan}

Pengelasan adalah ikatan metalorgi pada sambungan logam atau logam paduan yang dilaksanakan dalam keadaan lumer atau cair, dengan mempergunakan energi panas (Harsono Wiryosumarto dan Toshei Okumura, 1979). Khurmi dan Gupta (1980) mengemukakan mengelas adalah penyambungan dua logam bersama-sama dengan berbagai material, dalam pengelasan dapat menggunakan gas dan listrik. Las busur atau shielded metal arc welding adalah proses dalam pengelasan dengan busur nyala listrik dimana panas diperoleh dari busur jala yang memancar antara elektroda (dalam Selubung flux) dan benda kerja (Suharto, 1991). Sedangkan menurut, Suharto juga mengemukakan bahwa Las (welding) adalah suatu cara untuk menyambung benda padat dengan jalan mencairkannya melalui pemanasan. Klasifikasi las berdasarkan kesepakatan konvensional yang telah ada dibagi kedalam dua golongan, yaitu klasifikasi berdasarkan cara kerja dan klasifikai berdasarkan energi yang digunakan. Klasifikasi pertama membagi las dalam kelompok las cair, las tekan, las patri dan lain-lain. Sedangkan klasifikasi yang kedua membedakan adanya kelompok-kelompok seperti las listrik, las kimia, las mekanik dan seterusnya.

\section{Prinsip - Prinsip Las Listrik}

Las busur listrik atau pada umumnya disebut las listrik termasuk suatu proses penyambungan logam dengan menggunakan tenaga listrik sebagai sumber panas. Jadi sumber panas pada las listrik ditimbulkan oleh busur api arus listrik, antara elektroda las dan benda kerja.

Penggolongan macam proses las listrik antara lain ialah:

a. Las Listrik dengan Elektroda Karbon

b. Las Listrik dengan Elektroda Logam

Berdasarkan klasifikasi ini pengelasan dapat dibagi dalam tiga kelas utama, yaitu : pengelasan cair, pengelasan tekan, dan pematrian.

Pengelasan cair adalah cara pengelasan dimana sambungan dipanaskan sampai mencair dengan sumber panas dari busur listrik atau semburan api gas yang terbakar. (2) Pengelasan tekan adalah cara pengelasan dimana sambungan 
dipanaskan dan kemudian ditekan hingga menjadi satu. (3) Pematrian adalah cara pengelasan dimana sambungan diikat dan disatukan dengan menggunakan paduan logam yang mempunyai titik cair rendah. Dalam cara ini logam induk tidak turut mencair. Menurut Harsono Wiryosumarto dan Toshei Okumura (1979), bahwa Pengelasan adalah ikatan metalorgi pada sambungan logam atau logam paduan yang dilaksanakan dalam keadaan lumer atau cair, dengan mempergunakan energi panas. Sedangkan Khurmi dan Gupta (1980) mengemukakan mengelas adalah penyambungan dua logam bersama-sama dengan berbagai material, dalam pengelasan dapat menggunakan gas dan listrik. Las busur atau shielded metal arc welding adalah proses pengelasan dengan busur nyala listrik dimana panas diperoleh dari busur jala yang memancar antara elektroda (dalam Selubung flux) dan benda kerja.

Logam akan mengalami pengaruh pemanasan akibat pengelasan, dan mengalami perubahan struktur mikro disekitar daerah lasan. Bentuk struktur mikro logam disekitar daerah lasan bergantung pada temperatur tertinggi yang dicapai pada pengelasan, kecepatan pengelasan, dan laju pendinginan daerah lasan. Apabila struktur mikro logam mengalami perubahan, sifat mekanik logam tersebut juga akan mengalami perubahan. Daerah logam yang mengalami perubahan struktur mikro akibat mengalami pemanasan karena pengelasan, disebut Daerah Pengaruh Panas (DPP) atau Heat Affected Zone (HAZ). Perubahan struktur mikro dan perubahan sifat mekanik pada logam yang mengalami proses pengelasan inilah yang diteliti didalam Tugas Akhir ini. Perubahan struktur mikro dapat diteliti dengan pemeriksaan metalografi, dan perubahan sifat mekanik dapat di teliti dengan pengujian mekanik, yang dilakukan dengan uji tarik dan uji kekerasan. Adapun logam yang dilas adalah pelat Aluminium Paduan Seri 1145 menurut standard Aluminium Association (AA) di Amerika, sesuai basil pemeriksaan komposisi kimia. Proses pengelasan dilakukan dengan TIG Welding (Tungsten InertGas Welding).

\section{Hasil penelitian ini menunjukkan bahwa:}

1. Untuk kecepatan pengelasan tetap dan arus pengelasan semakin besar; maka daerah pengaruh panas (HAZ) sesmakin lebar, butir pada HAZ bertambah besar, kekerasan pada HAZ turun. Kekuatan tarik sambungan las maksimum ada arus pengelasan 90 Ampere.

2. Untuk besar arus pengelasan tetap dan kecepatan pengelasan semakin tinggi; maka daerah pengaruh panas (HAZ) semakin menyempit, butir pada HAZ semakin halus, kekerasan pada HAZ turun. Kekuatan tarik sambungan las maksimum pada kecepatan pengelasan $200 \mathrm{~mm} /$ menit.

\section{PERALATAN LAS}

Las gas tungsten (las TIG) adalah proses pengelasan dimana busur nyala listrik ditimbulkan oleh elektroda tungsten (elektroda tak terumpan) dengan benda kerja logam. Daerah pengelasan dilindungi oleh gas lindung (gas tidak aktif) agar tidak berkontaminasi dengan udara luar. Kawat las dapat ditambahkan atau tidak tergantung dari bentuk sambungan dan ketebalan benda kerja yang akan dilas. Perangkat yang dipakai dalam pengelasan las gas tungsten adalah:

\section{MESIN}

Mesin las $\mathrm{AC} / \mathrm{DC}$ merupakan mesin las pembangkit arus AC/DC yang digunakan di dalam pengelasan las gas tungsten. Pemilihan arus AC atau DC biasanya tergantung pada jenis logam yang akan dilas.

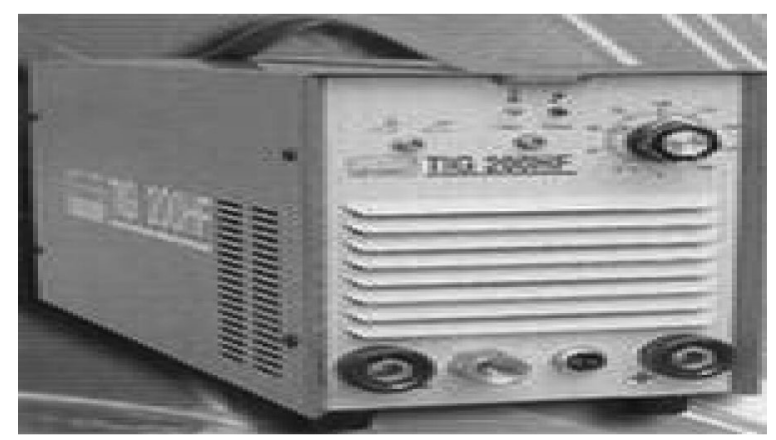

Gambar mesin las

\section{LAS TIG (TUNGSTEN INERT GAS)}

Gas Tungsten Arc Welding (GTAW) atau sering juga disebut Tungsten Inert Gas (TIG) merupakan salah satu dari bentuk las busur listrik (Arc Welding) yang menggunakan inert gas 
sebagai pelindung dengan tungsten atau wolfram sebagai elektrode. Skema dari GTAW dapat dilihat dalam Gambar, Pengelasan ini dikerjakan secara manual maupun otomatis.

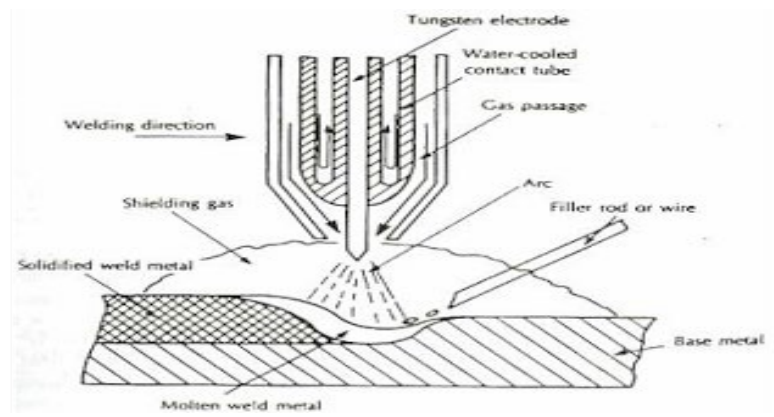

Gambar. Skema pengelasan TIG(tungsten inert gas)

Elektrode pada GTAW termasuk elektrode tidak terumpan (non consumable) berfungsi sebagai tempat tumpuan terjadinya busur listrik. GTAW mampu menghasilkan las yang berkualitas tinggi pada hampir semua jenis logam mampu las. Biasanya ini digunakan pada stainless steel dan logam ringan lainnya seperti alumunium, magnesium dan lain-lain hasil pengelasan pada teknik ini cukup baik tapi membutuhkan kemampuan yang tinggi.

Pada pengelasan TIG ini tenaga yang dibutuhkan adalah tenaga listrik baik AC maupun DC. Tenaga listik hanya digunakan sebagai pemanas dan hanya untuk membuat busur nyala pada elektroda, bagian bagian pemdukung lainnya masih disuplai dari alat lain. Peralatan yang sering digunakan sebagai pendukung dari las TIG ini adalah tabung gas Argon maupun gas lain yang dapat melindungi proses pengelasan dari pengaruh udara luar.

\section{METODE KEGIATAN}

\section{Tujuan Kegiatan} berikut:

Adapun Tujuan kegiatan ini adalah sebagai

1. Meningkatkan kompetensi sumber daya manusia, khususnya para mantan TKI, untuk mencapai standar kompetensi yang ditetapkan dalam peraturan perundangan yang berlaku.

2. Memutakhirkan kompetensi keterampilan para mantan TKI untuk memenuhi kebutuhan tenaga kerja, dalam perkembangan ilmu pengetahuan, dan teknologi untuk memfasilitasi proses sumber daya manusia yang berkualitas.

3. Meningkatkan sumberdaya manusia dalam melaksanakan tugas pokok dan fungsinya sebagai tenaga profesional.

4. Menumbuhkan rasa cinta dan bangga sebagai penyandang profesi pekerja yang berkulitas.

5. Meningkatkan citra, harkat, dan martabat di masyarakat.

6. Menunjang pengembangan karir para mantan TKI di bidang pengelasan.

\section{Manfaat Kegiatan}

Banyak manfaat yang dapat diperoleh dari kegiatan ini yaitu antara lain :

1. Bagi peserta pelatihan. Dengan adanya pelaksanaan pelatihan ini, maka peserta pelatihan memperoleh jaminan pelayanan dan pengalaman dalam praktek pengelasan yang efektif. Pelaksanakan pelatihan ini, akan dapat memenuhi standar dan mengembangkan kompetensinya sehingga mampu melaksanakan tugas-tugas utamanya secara efektif sesuai dengan kebutuhan tenaga kerja.

2. Bagi Pemerintah, dengan adanya pelatihan ini, akan memberikan jaminan kepada masyarakat tentang layanan pendidikan pelatihan praktek las yang berkualitas dan profesional.

\section{Khalayak Sasaran}

Para Mantan Tenaga kerja Indonesia (TKI) yang tidak pergi lagi ke luar negeri dan belum dapat pekerjaan tetap, dan mereka bekerja serabutan di jakarta. Para mantan TKI ini berasal dari Desa Teluk Labuan Pandeglang.

\section{Metode Penerapan Ipteks}

Pada pelatihan ini direncanakan pelaksanaannya sebanyak 6 latihan pertemuan yang masing-masing selama 2 jam. Pada pertemuan pertama diberikan secara umum tentang praktek pengelasan

Pada pertemuan 2 sampai ke 5 latihan praktik keterampilan las dan pertemuan ke 6 evaluasi. 


\section{Keterkaitan}

Kegiatan yang akan dilaksanakan ini mempunyai keterkaitan dengan berbagai institusi, yang antara lain adalah institusi/dinas tenaga kerja (Depnaker) industri, dll pada umumnya.

\section{HASIL DAN PEMBAHASAN Hasil Pelatihan}

Evaluasi untuk mengukur tingkat keberhasilan kegiatan ini dilakukan terhadap beberapa unsur, diantaranya frekuensi kehadiran, keseriusan selama pelatihan, dan penguasaan materi baik aspek teknik maupun manajemen perawatan bengkel las.

Berdasarkan pengamatan yang dilakukan, pelaksanaan kegiatan pengabdian ini berhasil dengan baik. Hal ini dapat dilihat dari frekuensi kehadiran yang tinggi dan keseriusan (ketekunan) selama berlatih. Penguasaan teknik pengelasan juga cukup baik lebih dari $85 \%$ peserta menguasai teknik yang baik dan benar, walaupun belum dapat dikatakan mahir. Dari pelatihan teknik pengelasan yang telah dikuasai ini diharapkan dapat dijadikan sebagai bekal untuk mengembangkan katerampilan lebih lanjut. Sebagaimana tujuan kegiatan untuk memberikan pelatihan keterampilan pengelasan dari dua aspek, yaitu aspek teknologi/teknik tentang pengelasan. Dalam aspek teknologi ini para pesertasi peserta pelatihan, diberi pelatihan yang berkaitan dengan alat dan perlengkapan mesin las, mengoprasikan mesin las, membuat program kerja job las. Pemeliharaan mesin las, dan Perbaikan mesin las, serta cara penangananya, dan berbagai teknik mesin bubut yang praktis, Dalam aspek manajemen, peserta akan diberi pelatihan tentang kiat-kiat atau langkah-langkah yang harus ditempuh dalam pemeliharaan mesin las.

Kegiatan pengabdian kepada masyarakat ini dapat manfaat bagi para peserta pelatihan, hingga dapat meningkatkan kualitas sumberdaya manusia, dari semula tidak terampil menjadi lebih terampil dan mempunyai keahlian menjadikan terampil dalam pengelasan yang professional. Menjadikan para TKI terampil bidang permesinan las. Menjadikan para TKI yang berkualitas sesuai dengan bidangnya di pengelasan. Membantu pemerintah dalam meningkatkan kualitas sumber daya manusia. Sebagai upaya membantu pemerintah dalam mengatasi kekurangan ahli dalam pengelasan menjadi pekerja yang profesional.

\section{Hasil Pembahasan}

Berdasarkan hasil atau realisasi pelaksanaan kegiatan pelatihan, maka dapat dijelaskan berdasarkan dua faktor, yaitu faktor penunjang dan faktor penghambat.

Faktor yang dapat dikatakan sebagai penunjang antara lain adalah minat peserta yang tinggi, tersedianya prasarana dan sarana yang cukup memadai, seperti tempat, bahan, dan alat-alat yang cukup. Selain itu kegiatan ini juga mendapat respons dan dukungan yang baik dari Masyarakat Desa Teluk-Labuan, hal ini dibuktikan dengan kehadiran Pak Camat dan Kepala Desa dan Jajarannya. Adapun faktor penghambat yang utama adalah tingginya harga bahan-bahan dan peralatan untuk kegiatan saat ini, seperti besi, majun, hamplas dan sebaginya. Oleh karena itu kegiatan ini tidak dapat dilakukan secara optimal, dalam arti dapat menggunakan bahan yang banyak dan jangka waktu yang lebih lama, karena keterbatasan anggaran yang tersedia.

Hambatan lain adalah dari segi waktu kegiatan perjalaanan yang cukup jauh. Dan Para Instruktur harus menginap.

Namum demikian, secara keseluruhan kegiatan pengabdian kepada masyarakat dalam bentuk pelatihan keterampilan pengelasan, dan manajemen bengkel ini cukup berarti dan mempunyai nilai tambah tersendiri bagi khalayak sasaran khususnya, dan masyarakat desa teluklabuan pada umumnya.

\section{Observasi Kegiatan}

Pada kegiatan ini diadakan observasi kegiatan terhadap peserta pelatihan dan evaluasi terhadap program pelatihan. Evaluasi terhadap peserta pelatihan dilalukan oleh anggota tim dengan membuktikan setiap peserta pelatihan telah membuat benda kerja job pengelasan dan dipraktikan hasilnya menjadi benda kerja. Evaluasi program kegiatan ini dilakukan untuk mengetahui tingkat ketercapian dari tujuan program kegiatan yang dilaksanakan. Kegiatan evaluasi dilaksanakan sebelum, selama dan sesudah kegiatan pelatihan berlangsung. Evaluasi sebelum kegiatan dilaksanakan dengan cara diskusi sebelum pemaparan materi dan sebelum pelaksanaan praktik. Sedang evaluasi selama kegiatan berlangsung dilakukan dengan mengamati para peserta pelatihan. 
Setelah itu dilakukan evaluasi dengan cara para peserta pelatihan membuat program kerja job untuk di eksekusi dalam praktik las, dan hasilnya melihat benda kerja hasil praktik para peserta pelatihan untuk melihat keberhasilan, ternyata cukup memuaskan.

\section{Hasil Kegiatan}

Berdasarkan hasil pelatihan didapatkan suatu perubahan yang baik bagi para perserta pelatihan, yang sebelumnya tidak begitu paham tentang pengelasan. Sekarang memiliki kemampuan untuk mengerjakan pengelasan membuat pagar, teralis pintu, perbaikan las kapal/perahu ikan. Kegiatan pengabdian kepada masyarakat ini mempunyai beberapa hasil sebagai berikut:

a) Peserta pelatihan (mantan TKI) dapat meningkatkan kualitas sumberdaya manusia, dari semula tidak terampil mengelas menjadi lebih terampil dan mempunyai keahlian menjadikan pekerja pengelasan yang professional.

b) Mantan TKI yang berkualitas sesuai dengan bidangnya pengelasan.

\section{KESIMPULAN DAN SARAN KESIMPULAN}

Terdapat dua aspek materi pelatihan yang diberikan terhadap para mantan TKI, yaitu aspek teknik keterampilan pengelasan dan aspek manajemen wirausaha bengkel las. Berdasarkan evaluasi yang telah dilaksanakan, dari aspek teknik, pelatihan ini dapat dikatakan cukup berhasil. Lebih dari $90 \%$ peserta menguasai teknik pengelasan dengan baik. Untuk aspek manajemen wirausaha bengkel las, Berdasarkan evaluasi yang telah dilaksanakan, dari aspek teknik, pelatihan ini dapat dikatakan cukup berhasil. Mengingat waktu kegiatan pengabdian yang terbatas, maka evaluasi terhadap aspek manajemen belum dilakukan. Namun demikian secara umum kegiatan pengabdian ini mendapat respons yang positif dari para peserta pelatihan mantan TKI. khususnya, dan masyarakat desa Teluk-Labuan pada umumnya.

\section{SARAN}

Berkaitan dengan pelaksanaan kegiatan ini, saran yang dapat disampaikan:

1. Bagi para peserta latihan, bekal pengetahuan dan keterampilan yang telah dimiliki ini hendaknya dikembangkan sendiri. Cara yang dapat ditempuh misalnya, buka usaha bengkel las.

2. Bagi tim pelaksana kegiatan pengabdian, supaya dipertimbangkan untuk mengadakan pelatihan yang sama namun dengan materi yang lebih mendalam di tahun mendatang. Tujuannya adalah agar tercapainya tujuan akhir yang diharapkan. yaitu menjadikan para peserta mantan TKI yang professional pada bidangnya.

3. Ada baiknya para peserta tetap mengembangkan latihan-latihan praktik pengelasan .

\section{DAFTAR PUSTAKA}

Shigley, Joseph Edward and Larry D. Mitchell, Perencanaan Teknik Mesin, diterjemahkan oleh Gandhi Harahap, cetakan kedua, Jakarta: Erlangga, 2011.

Suga Kiyokatsu, Dasar Perencanaan dan Pemilihan Elemen Mesin, Terjemahan: Sularso, cetakan ketujuh, Jakarta: Pradnya paramita, 1991.

Dudung, Agus. Teknik Pengelasan, Bandung: CV. Bakti Aksara, 2010. 